\title{
Percutaneous cholecystostomy instead of laparoscopy to treat acute cholecystitis during the COVID-19 pandemic period: single center experience
}

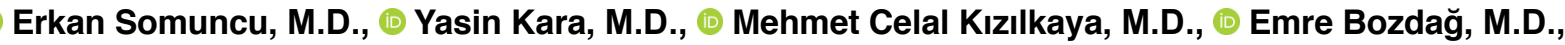

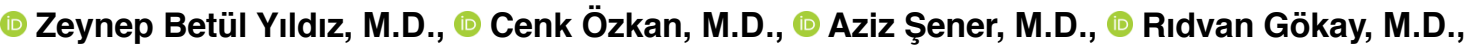

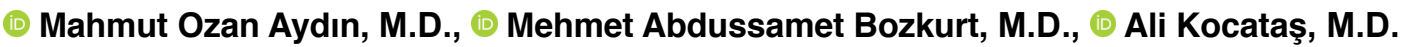

Department of General Surgery, University of Health Sciences, Kanuni Sultan Suleyman Training and Research Hospital, İstanbul-Turkey

\begin{abstract}
BACKGROUND: Laparoscopic cholecystectomy (LC) is the accepted standard treatment for acute cholecystitis (AC) in patients eligible for surgery. Percutaneous cholecystostomy (PC) can provide a permanent treatment for high-risk patients for surgery or act as a bridge for later surgical treatment. This study is an evaluation of the use of PC during the current coronavirus 2019 (COVID-19) pandemic at a single hospital.

METHODS: Fifty patients with AC were admitted as of the start of the COVID-19 pandemic in Turkey through June 2020. Patients with pancreatitis, cholangitis, and/or incomplete data were excluded from the study. Data of the remaining 36 patients included in the study were recorded and a descriptive statistical analysis was performed. The patients were divided into three groups: PC ( $\mathrm{n}=\mid 4$ ), only conservative treatment with antibiotherapy $(O C)(n=14)$, and LC $(n=8)$. The findings were compared with a group of 70 similar patients from the pre-pandemic period.

RESULTS: The mean age of the pandemic period patients was 53 years (range: $26-78$ years). The female/male ratio was I.II. PC was preferred in eight $(11 \%)$ patients in the same period of the previous year, whereas $14(39 \%)$ patients underwent PC in the pandemic period. Four of the 36 pandemic patients were positive for COVID-19, including one member of the PC group. There was one (7.I\%) mortality in the pandemic-period PC group due to cardiac arrest. The length of hospital stay between the groups based on the type of treatment was not statistically significant.
\end{abstract}

CONCLUSION: LC is not recommended during the pandemic period; PC can be an effective and safe alternative for the treatment of $A C$.

Keywords: Acute cholecystitis; COVID-19 pandemic; percutaneous cholecystostomy.

\section{INTRODUCTION}

Acute cholecystitis (AC) is one of the most common surgical emergencies. $A C$ has the potential to cause sepsis and death in patients with comorbidities. ${ }^{[1-3]}$ The most common cause is gallstones; however, it may also be associated with diabetes, immunosuppression, chronic kidney disease, viral disease, hemoglobinopathies, or vasculitis. ${ }^{[4]}$ The optimal treatment for $A C$ is early surgery. The standard procedure is a laparoscopic cholecystectomy (LC). ${ }^{[5]}$ In most patients, antibiotherapy is initiated and underlying diseases are controlled. Although severe sepsis may be present in some patients, surgery may not be possible due to accompanying critical conditions and poor physiological reserve. Alternative treatment options, such as percutaneous cholecystostomy (PC), may be preferred in these patient groups. ${ }^{[6]}$

Cite this article as: Somuncu E, Kara Y, Kızılkaya MC, Bozdağ E, Yıldız ZB, Özkan C, et al. Percutaneous cholecystostomy instead of laparoscopy to treat acute cholecystitis during the COVID-19 pandemic period: A case series experience. Ulus Travma Acil Cerrahi Derg 2021;27:89-94.

Address for correspondence: Erkan Somuncu, M.D.

Sağlık Bilimleri Üniversitesi, Kanuni Sultan Süleyman Eğitim ve Araştırma Hastanesi, Genel Cerrahi Kliniği, İstanbul, Turkey

Tel: +90 212 - 4041500 / 1424 E-mail: dr.somuncu@gmail.com 
The Intercollegiate General Surgery Guidance on COVID-19 [7] of the United Kingdom has recommended that nonoperative management should be performed when possible during the novel coronavirus disease 2019 (COVID-19) outbreak. Other surgical communities, including the Italian Society of Endoscopic Surgery (SICE), the Society of American Gastrointestinal and Endoscopic Surgeons (SAGES), and the European Association of Endoscopic Surgery (EAES), have also proposed a patient-centered and hospital-centered approach. ${ }^{[8-10]}$ In the article "Recommendations for trauma and emergency general surgery practice during COVID-19" published by Gok et al., ${ }^{[1]}$ from Turkey, it was stated that percutaneous cholecystostomy (PC) is a potential alternative to cholecystectomy and can be used if antibiotic treatment fails. A recent multicentric, international study reported that any surgery in patients with a preor perioperative COVID- 19 infection resulted in $25 \%$ mortality and severe pulmonary complications in $51 \%$. Conservative approaches were recommended as much as possible for many surgical indications. It was also noted that laparoscopic cholecystectomy (LC) in acute cholecystitis was a high-risk procedure for surgical teams during the COVID-19 pandemic. ${ }^{[2]}$

The present study aims to examine the approach used with AC patients in a tertiary hospital during the ongoing pandemic in contrast to the period before the pandemic.

\section{MATERIALS AND METHODS}

In this study, 50 patients with acute calculous cholecystitis were admitted to the general surgery clinic of Kanuni Sultan Suleyman Training and Research Hospital between March 10, 2020 (first recorded COVID-19 case in Turkey publicly announced on March II) and June I0, 2020. However, 70 patients who were diagnosed with cholecystitis during the same period of 2019 were included in the analysis based on the same criteria. In all, 14 patients with coexisting pancreatitis, cholangitis, or incomplete data were excluded from this research. The study cohort for the pandemic period consisted of 36 patients.

The data of all of the patients were recorded, descriptive statistical analysis was performed, and the results of the two time periods were compared. During the pandemic period, treatment for cholecystitis was based on the surgeon's and patient's preference and was primarily non-surgical. The patients were divided into three subgroups: Group I comprised patients who underwent PC $(n=14)$, Group 2, the OC group, received only conservative treatment with antibiotherapy $(n=14)$, and Group 3 comprised those who underwent LC $(n=8)$. The 14 patients in Group I were at high surgical risk due to acute or chronic comorbidity. An interventional radiologist performed ultrasound (US)-guided transhepatic PC under local anesthesia with a pigtail catheter. In all groups, oral food intake was regulated according to the patient's clinical condition, and the decision to discharge was evaluated based on food tolerance.
This research was performed according to the principles of the Helsinki Declaration. Written informed consent was provided by all of the participating patients. All 36 patients in the pandemic group had impaired gallbladder wall integrity (intraparenchymal fluid in the gallbladder bed or excess fluid around the gallbladder with gallbladder distension) observed on contrast-enhanced abdominal computed tomography images (CT) or the US performed upon admission. The diagnosis of $A C$ was confirmed based on the clinical examination, biochemical parameters, and both US and CT imaging in all three groups. COVID-19 was confirmed with a thorax CT before hospitalization without waiting for polymerase chain reaction test results.

Among the patients who underwent PC, some required daily, recurrent saline irrigation through the cholecystectomy drainage catheter to remove any gallbladder debris and fluid. Oral food intake was initiated when postprocedural recovery was observed, and solid foods were administered gradually. Patients were discharged following training regarding changing the dressing around the cholecystostomy entry site, evacuation of the cholecystectomy tube, and provided with an oral antibiotic prescription, diet recommendations, and an outpatient appointment. All of the patients were followed up by the same surgeon who performed their procedure in the general surgery outpatient clinic. At an average of three weeks later, they were evaluated by the same surgeon and the radiologist who inserted the catheter. In the PC Group, additional follow-up was recommended for patients with an open cystic duct, and LC was planned for patients with insufficient gallbladder discharge.

The Tokyo guidelines for $A C$ recommend $P C$ in cases not exhibiting recovery on the fifth day despite treatment in surgically high-risk patients (discontinuation of oral intake, intravenous hydration, and intravenous ceftriaxone treatment). According to the guidelines, an interval cholecystectomy is performed four to six weeks after the PC procedure. ${ }^{[13]}$ However, we performed an urgent US-guided PC in high-risk patients with AC if the gallbladder was hydropic. Once pandemic conditions permit it, these patients will be called for an interval cholecystectomy.

\section{Statistical Analysis}

The outcomes of the study patients were investigated retrospectively. IBM SPSS Statistics for Windows, Version 22.0 (IBM Corp., Armonk, NY, USA) was used to perform the data analyses. Descriptive statistics were used for demographic and clinical features. The results were presented as percentages for continuous variables and the number/percentage for categorical variables.

\section{RESULTS}

\section{Demographic Characteristics of all Patients}

The median age of the 36 patients in the pandemic group 
was 53 years (range: $26-78$ years). Of these, 17 were male and 19 were female. The female/male ratio was I.I. Four of the 36 patients were positive for COVID-19. One of the COVID-19-positive patients underwent a PC, one patient had an LC, and two patients were treated conservatively with antibiotherapy. There was no mortality or additional pulmonary complications in the follow-up of COVID-19-positive patients.

In the same period of 2019 (March-June), before the pandemic, 70 patients were diagnosed with AC. Twenty-one underwent an emergency cholecystectomy (I 8 laparoscopic, three open surgery), 4I were treated conservatively with antibiotherapy, and eight underwent a PC. While the median age of the PC patients was 79 years in the earlier period, the median age of patients in the pandemic period was 68 years. This is a result of a preference for $P C$ in patients with $A C$ during the pandemic in order to protect the surgical team and the patients from COVID-19 infection.

\section{Comparison of Groups and Evaluation of Results during the Pandemic Period}

The median age of patients was 68 years (range: 26-76 years) in the pandemic period PC group, and the female/male ratio was I/I. The median hospital stay was seven days (range: 2-20 days). Ten patients in the PC group had several comorbidities, as shown in Table I. In all patients, the symptoms and biochemical parameters improved after the PC. The median hospital stay after the PC procedure was seven days (range: 2-20 days). During the pandemic period, an LC was

Table I. Demographic features of percutaneous cholecystostomy cases

\begin{tabular}{|c|c|c|c|c|c|c|c|}
\hline Patient ID & Age & Sex & US/CT/MR & Hospital stay (days) & Additional disease & COVID-19 & Catheter removal (days) \\
\hline I & 73 & Female & $+/+/-$ & 5 & CAD, CHF & Negative & 35 \\
\hline $2^{*}$ & 66 & Female & $+/+/-$ & 2 & AGC & Negative & - \\
\hline 3 & 76 & Female & $+/+/+$ & 7 & - & Pozitive & 15 \\
\hline 4 & 72 & Female & $+/+/+$ & 6 & HT, DM & Negative & 24 \\
\hline 5 & 74 & Male & $+/+/-$ & 3 & - & Negative & 19 \\
\hline 6 & 70 & Female & $+/+/-$ & 4 & $\mathrm{AF}$ & Negative & 25 \\
\hline 7 & 47 & Male & $+/+/-$ & 9 & DM, CABG & Negative & 25 \\
\hline 8 & 43 & Male & $+/+/-$ & 20 & SP & Negative & 23 \\
\hline 9 & 49 & Male & $+/+/-$ & 7 & - & Negative & 24 \\
\hline 10 & 71 & Female & $+/+/-$ & 10 & HT, DM & Negative & 27 \\
\hline II & 45 & Male & $+/+/-$ & 3 & CAD & Negative & II \\
\hline 12 & 76 & Female & $+/+/-$ & 7 & $\mathrm{CH}$ & Negative & 20 \\
\hline 13 & 60 & Male & $+/+/-$ & 14 & $\mathrm{HT}$ & Negative & 10 \\
\hline 14 & 26 & Male & $+/+/+$ & 7 & - & Negative & 20 \\
\hline
\end{tabular}

*Exitus (cardiac arrest). AGC: Advanced gastric cancer; AF: Atrial fibrillation; CABG: Coronary artery bypass grafting; CAD: Coronary artery disease; CH: Congenital hypothyroidism; CHF: Congestive heart failure; CT: Computed tomography; DM: Diabetes mellitus; HT: Hypertension; MR: Magnetic resonance; SP: Cerebral palsy; US: Ultrasound.

Table 2. Distribution of acute cholecystitis cases by the group during the COVID-19 pandemic periods

\begin{tabular}{|c|c|c|c|}
\hline & \multicolumn{3}{|c|}{ Groups } \\
\hline & $\begin{array}{l}\text { Percutaneous }(n=14) \\
\text { cholecystostomy }\end{array}$ & $\begin{array}{l}\text { Laparoscopic }(n=8) \\
\text { cholecystectomy }\end{array}$ & $\begin{array}{l}\text { Only conservative treatment } \\
\text { with antibiotherapy }(n=14)\end{array}$ \\
\hline Male/female & $6 / 8$ & $4 / 4$ & $7 / 7$ \\
\hline Median age (years) & $68(26-76)$ & $44(31-63)$ & $50(26-78)$ \\
\hline Median hospital stay (days) & $7(2-20)$ & $3(2-16)$ & $4(2-9)$ \\
\hline Median catheter removal (days) & $21(10-35)$ & - & - \\
\hline Additional disease & $10 / 14$ & $2 / 8$ & $5 / 14$ \\
\hline Readmission to hospital & $1 / 14$ & $1 / 8$ & $0 / 14$ \\
\hline Coronavirus disease 2019 positivity & $1 / 14$ & $1 / 8$ & $2 / 14$ \\
\hline
\end{tabular}


performed in one patient in the PC group after catheter removal and during the initial admission in the remaining eight patients.

Fourteen patients from the pandemic group were followed up with antibiotherapy alone. All were discharged after clinical and biochemical recovery. The median length of hospital stay in this group was four days (range: 2-9 days) (Table 2).

The median duration of hospital stay was three days (range: 2-I6 days) for the LC group. The length of hospital stay was lower in the OC and LC groups when compared with the PC group, but the difference was not statistically significant.

In $18(50 \%)$ members of the pandemic period cohort, the American Society of Anesthesiology (ASA) score was IV or greater, and II (60\%) patients underwent PC.

One patient in the PC group re-applied to the hospital due to the displacement of the catheter. Apart from this, no other complications were seen in the PC group. Superficial wound infection, which was treated with simple drainage and antibiotherapy, was detected in the four patients in the LC group. None of the patients developed additional morbidity. There was one $(7.1 \%)$ mortality in the PC group due to cardiac arrest.

\section{DISCUSSION}

Current guidelines state that the definitive treatment for cholecystitis is an LC. ${ }^{[1-16]}$ However, for reasons, such as concomitant diseases and sepsis, surgery may not always be appropriate or safe for every patient. PC, which is a potentially life-saving and less invasive treatment option, may be preferred for patients in this category. ${ }^{[17]}$ PC can serve as a bridge therapy that allows patients to survive severe disease and stabilize until they have a cholecystectomy. ${ }^{[4]}$

LC continues to be the first-line treatment for $A C$, even during the COVID-19 pandemic period. ${ }^{[18]}$ However, many studies have emphasized that many toxic components in surgical smoke may endanger the health of the surgical team. It has been established that viruses (human papillomavirus, hepatitis B virus, HIV) can be transmitted via blood in this smoke. ${ }^{[18,19]}$ Although there is no evidence of the presence of severe acute respiratory syndrome coronavirus 2 (SARSCoV-2), which causes COVID-19, in surgical smoke, SARSCoV-2 RNA has recently been detected in the peritoneal cavity. ${ }^{[20]}$ Many studies suggest filtering the pneumoperitoneum to remove most viral particles during laparoscopy. ${ }^{[9,10,21]}$ We were unable to procure this filter at our hospital.

In Italian, Turkish, and the latest World Society of Emergency Surgery guidelines, it has been stated that percutaneous drainage of the gallbladder may be an alternative treatment after conservative treatment with antibiotics has been unsuc- cessful in patients who are not candidates for surgery. ${ }^{[1,15,16,22]}$ The optimal timing of PC is controversial. However, when performed within 24 hours from the clinical presentation, it is associated with fewer complications and a shorter hospital stay. As reported by Campanile et al., ${ }^{[23]}$ we also think that the timing of a PC primarily depends on clinical indications. For example, emergency drainage should be considered in a patient with severe sepsis not suitable for surgery. In other patients who are not suitable candidates for surgery, it is common practice to perform a cholecystostomy if there is no improvement within one to three days after starting antibiotic treatment unless sepsis is present.

In the literature, US-guided percutaneous transhepatic gallbladder drainage is considered the first alternative to surgical intervention in surgically high-risk patients with AC. PC also involves placing the catheter into the gallbladder with US guidance. PC is a well-defined, effective method to ensure immediate decompression of the inflamed gallbladder; it can reduce the risk of both inflammation and bile duct injury in patients whose general condition does not permit an emergency cholecystectomy. With a response rate ranging from $56 \%$ to $100 \%$ in the literature, PC provides early recovery and shortens the hospital stay. The potential early complications are bleeding, vagal reactions, sepsis, biliary peritonitis, pneumothorax, intestinal perforation, secondary infection, and catheter displacement, while late complications can include catheter displacement and recurrent cholecystitis. ${ }^{[24-29]}$ In our study, we observed two instances of catheter dislocation in one patient of the PC group during the pandemic period, and catheter replacement was required.

One drawback of a PC is the development of fibrosis between the gallbladder and the liver in most patients. ${ }^{[30]}$ This makes performing a cholecystectomy laparoscopically difficult. In a study that presented the results of 245 AC cases that underwent PC, it was reported that only 7I underwent cholecystectomy. Conversion to open surgery was necessary for $13(21 \%)$ of 63 patients who started laparoscopically. Laparoscopy was successfully completed in 50 (79\%) patients. ${ }^{[3 \mathrm{I}]}$ In many studies, LC has been reported to be a feasible and reliable approach in the treatment of AC. Following the literature, we started all of the cholecystectomies laparoscopically.

Several studies have shown that positive results have been achieved in the short term with a PC. ${ }^{[17]}$ However, the longterm effects are controversial because there is conflicting information in the literature about the procedure-related risks. Dimou et al. ${ }^{[32]}$ reported that a PC was preferable to cholecystectomy in the treatment of AC since the implementation of the Tokyo guidelines. Unlike our research, they also found that PC was associated with increased re-admission and higher mortality rates.

We have primarily preferred to pursue a PC in cases of $A C$ since the COVID-19 pandemic. Our patients had significant 
comorbidities, and generally, ASA scores of IV or more. We have seen that PC can be successful and maybe preferable, not only in critical situations for the patient but also in critical situations for the surgical team.

\section{Conclusion}

PC was recommended and preferred to surgery in the initial treatment of AC, especially in high-risk, critically ill patients before the COVID-19 pandemic. Laparoscopic and endoscopic procedures are not recommended during the pandemic. PC can be an effective and safe alternative to treat $A C$ during the pandemic period.

Informed Consent: Written informed consent was obtained from patients who participated in this study.

Peer-review: Internally peer-reviewed.

Authorship Contributions: Concept: E.S., Y.K.; Design: E.S., Y.K.; Supervision: E.S., Y.K.; Resource: E.S., Y.K., M.C.K., E.B., A.S.; Materials: E.S., Z.B.Y., C.Ö., R.G., M.O.A.; Data: E.S., Z.B.Y., C.Ö., R.G., M.O.A.; Analysis: E.S., Y.K.; Literature search: E.S., Y.K.; Writing: E.S.; Critical revision: E.S., Y.K., M.A.B, A.K.

\section{Conflict of Interest: None declared.}

Financial Disclosure: The authors declared that this study has received no financial support.

\section{REFERENCES}

1. Bala M, Mizrahi I, Mazeh H, Yuval J, Eid A, Almogy G. Percutaneous cholecystostomy is safe and effective option for acute calculous cholecystitis in select group of high-risk patients. Eur J Trauma Emerg Surg 2016;42:761-6. [CrossRef]

2. Borzellino G, Sauerland S, Minicozzi AM, Verlato G, Di Pietrantonj C, de Manzoni G, et al. Laparoscopic cholecystectomy for severe acute cholecystitis. A meta-analysis of results. Surg Endosc 2008;22:8-15. [CrossRef]

3. Giger UF, Michel JM, Opitz I, Th Inderbitzin D, Kocher T, Krähenbühl L; Swiss Association of Laparoscopic and Thoracoscopic Surgery (SALTS) Study Group. Risk factors for perioperative complications in patients undergoing laparoscopic cholecystectomy: analysis of 22,953 consecutive cases from the Swiss Association of Laparoscopic and Thoracoscopic Surgery database. J Am Coll Surg 2006;203:723-8. [CrossRef]

4. Aroori S, Mangan C, Reza L, Gafoor N. Percutaneous Cholecystostomy for Severe Acute Cholecystitis: A Useful Procedure in High-Risk Patients for Surgery. Scand J Surg 2019;108:124-9. [CrossRef]

5. Yamashita Y, Takada T, Strasberg SM, Pitt HA, Gouma DJ, Garden OJ, et al; Tokyo Guideline Revision Committee. TG13 surgical management of acute cholecystitis. J Hepatobiliary Pancreat Sci 2013;20:89-96. [CrossRef]

6. Pang KW, Tan CH, Loh S, Chang KY, Iyer SG, Madhavan K, et al. Outcomes of Percutaneous Cholecystostomy for Acute Cholecystitis. World J Surg 2016;40:2735-44. [CrossRef]

7. Royal College of Surgeons of England. Updated Intercollegiate General Surgery Guidance on COVID-19. Available from: https://www.rcseng. ac.uk/coronavirus/joint-guidance-for-surgeons-v2/.

8. SICE. Guida in tema di Chirurgia durante la pandemia COVID-19. Available from: https://siceitalia.com/guida-in-tema-di-chirurgia-durante-la-pandemia-covid-19/.
9. EAES. Category: COVID-19 Statements. Availabe from: https://eaes. eu/category/covid-19-statements/

10. SAGES. SAGES COVID-19 / Coronavirus Announcement Archives. Available from: https://www.sages.org/category/covid-19/

11. Gok AFK, Eryılmaz M, Ozmen MM, Alimoglu O, Ertekin C, Kurtoglu $\mathrm{MH}$. Recommendations for Trauma and Emergency General Surgery Practice During COVID-19 Pandemic. Ulus Travma Acil Cerrahi Derg 2020;26:335-42. [CrossRef]

12. COVID Surg Collaborative. Mortality and pulmonary complications in patients undergoing surgery with perioperative SARS-CoV-2 infection: an international cohort study. Lancet 2020;396:27-38. [CrossRef]

13. Mori Y, Itoi T, Baron TH, Takada T, Strasberg SM, Pitt HA, et al. Tokyo Guidelines 2018: management strategies for gallbladder drainage in patients with acute cholecystitis (with videos). J Hepatobiliary Pancreat Sci 2018;25:87-95. [CrossRef]

14. Agresta F, Campanile FC, Vettoretto N, Silecchia G, Bergamini C, Maida $\mathrm{P}$, et al. Laparoscopic cholecystectomy: consensus conference-based guidelines. Langenbeck's Arch Surg 2015;400:429-53. [CrossRef]

15. Ansaloni L, Pisano M, Coccolini F, Peitzmann AB, Fingerhut A, Catena F, et al. 2016 WSES guidelines on acute calculous cholecystitis. World J Emerg Surg 2016;11:25. [CrossRef]

16. Agresta F, Ansaloni L, Baiocchi GL, Bergamini C, Campanile FC, Carlucci $\mathrm{M}$ et al. Laparoscopic approach to acute abdomen from the Consensus Development Conference of the Società Italiana di Chirurgia Endoscopica e nuove tecnologie (SICE), Associazione Chirurghi Ospedalieri Italiani (ACOI), Società Italiana di Chirurgia (SIC), Società Italiana di Chirurgia d'Urgenza e del Trauma (SICUT), Società Italiana di Chirurgia nell'Ospedalità Privata (SICOP), and the European Association for Endoscopic Surgery (EAES). Surg Endosc 2012;26:2134-64. [CrossRef]

17. Wang CH, Wu CY, Yang JC, Lien WC, Wang HP, Liu KL, et al. LongTerm Outcomes of Patients with Acute Cholecystitis after Successful Percutaneous Cholecystostomy Treatment and the Risk Factors for Recurrence: A Decade Experience at a Single Center. PLoS One 2016;11:e0148017. [CrossRef]

18. Alp E, Bijl D, Bleichrodt RP, Hansson B, Voss A. Surgical smoke and infection control. J Hosp Infect 2006;62:1-5. [CrossRef]

19. Kwak HD, Kim SH, Seo YS, Song KJ. Detecting hepatitis B virus in surgical smoke emitted during laparoscopic surgery. Occup Environ Med 2016;73:857-63. [CrossRef]

20. Coccolini F, Tartaglia D, Puglisi A, Giordano C, Pistello M, Lodato M, et al. SARS-C oV-2 is present in peritoneal fluid in COVID-19 patients. Ann Surg 2020:272;240-2. [CrossRef]

21. Mintz Y, Arezzo A, Boni L, Chand M, Brodie R, Fingerhut A; the Technology Committee of the European Association for Endoscopic Surgery. A Low-cost, Safe, and Effective Method for Smoke Evacuation in Laparoscopic Surgery for Suspected Coronavirus Patients. Ann Surg 2020;272:e7-e8. [CrossRef]

22. Pisano M, Ceresoli M, Cimbanassi S, Gurusamy K, Coccolini F, Borzellino G, et al. 2017 WSES and SICG guidelines on acute calcolous cholecystitis in elderly population. World J Emerg Surg 2019;14:10. [CrossRef]

23. Campanile FC, Podda M, Arezzo A, Botteri E, Sartori A, Guerrieri M, et al. Acute cholecystitis during COVID-19 pandemic: a multisocietary position statement. World J Emerg Surg 2020;15:38. [CrossRef]

24. Boland GW, Lee MJ, Leung J, Mueller PR. Percutaneous cholecystostomy in critically ill patients: early response and final outcome in $82 \mathrm{pa}-$ tients. AJR Am J Roentgenol 1994;163:339-42. [CrossRef]

25. Dvorak P, Hoffmann P, Renc O, Dusek T, Rejchrt S, Slezak O, et al. Percutaneous cholecystostomy in the management of acute cholecystitis - 10 years of experience. Wideochir Inne Tech Maloinwazyjne 2019;14:516-25. 
26. Pavurala RB, Li D, Porter K, Mansfield SA, Conwell DL, Krishna SG. Percutaneous cholecystostomy-tube for high-risk patients with acute cholecystitis: current practice and implications for future research. Surg Endosc 2019;33:3396-403. [CrossRef]

27. Kuan LL, Oyebola T, Mavilakandy A, Dennison AR, Garcea G. Retrospective Analysis of Outcomes Following Percutaneous Cholecystostomy for Acute Cholecystitis. World J Surg 2020;44:2557-61. [CrossRef]

28. Morales-Maza J, Rodríguez-Quintero JH, Santes O, Hernández-Villegas AC, Clemente-Gutiérrez U, Sánchez-Morales GE, et al. Percutaneous cholecystostomy as treatment for acute cholecystitis: What has happened over the last five years? A literature review. Rev Gastroenterol Mex 2019;84:482-91. [CrossRef]

29. Cartı EB, Kutlutürk K. Should percutaneous cholecystostomy be used in all cases difficult to manage?. Ulus Travma Acil Cerrahi Derg 2020;26:186-90. [CrossRef]

30. Paran H, Zissin R, Rosenberg E, Griton I, Kots E, Gutman M. Prospective evaluation of patients with acute cholecystitis treated with percutaneous cholecystostomy and interval laparoscopic cholecystectomy. Int J Surg 2006;4:101-5. [CrossRef]

31. Khasawneh MA, Shamp A, Heller S, Zielinski MD, Jenkins DH, Osborn JB, et al. Successful laparoscopic cholecystectomy after percutaneous cholecystostomy tube placement. J Trauma Acute Care Surg 2015;78:100-4. [CrossRef]

32. Dimou FM, Adhikari D, Mehta HB, Riall TS. Outcomes in Older Patients with Grade III Cholecystitis and Cholecystostomy Tube Placement: A Propensity Score Analysis. J Am Coll Surg 2017;224:502-11.e1. [CrossRef]

\section{ORIJINAL MAKALE - ÖZET}

\section{COVID-19 salgını döneminde akut kolesistit tedavisinde laparoskopi yerine} perkütan kolesistostomi: Tek merkez deneyimi

Dr. Erkan Somuncu, Dr. Yasin Kara, Dr. Mehmet Celal Kızılkaya, Dr. Emre Bozdağ,

Dr. Zeynep Betül Yıldız, Dr. Cenk Özkan, Dr. Aziz Şener, Dr. Rıdvan Gökay,

Dr. Mahmut Ozan Aydın, Dr. Mehmet Abdussamet Bozkurt, Dr. Ali Kocataş

Sağlık Bilimleri Üniversitesi, Kanuni Sultan Süleyman Eğitim ve Araştırma Hastanesi, Genel Cerrahi Kliniği, İstanbul

AMAÇ: Laparoskopik kolesistektomi (LC), cerrahi için uygun hastalarda akut kolesistit (AC) için kabul edilen standart tedavidir. Perkütan kolesistostomi (PC), yüksek riskli hastalar için cerrahi için kalıcı bir tedavi sağlayabilir veya cerrahi tedavi için bir köprü görevi görebilir. PC'yi COVID- I9 pandemisinde değerlendirdik.

GEREÇ VE YÖNTEM: AC'li 50 hasta COVID-19 salgınının başlangıcından Haziran 2020'ye kadar kabul edildi. Pankreatit, kolanjit ve/veya eksik veriler çalışmadan çıkarıldı. Kalan 36 hastanın tümü kaydedildi ve tanımlayıcı istatistiksel analiz elde edildi. Hastalar üç gruba ayrıldı: PC ( $n=\mid 4$ ); Sadece antibiyoterapi (OC) $(n=14)$ ve LC $(n=8)$ ile konservatif tedavi.

BULGULAR: Ortalama yaş 53 (dağılım: 26-78 yıl) idi. Kadın/erkek oranı I. I I'dir. PC geçen yıl aynı dönemde sekiz (\%। I) hastada, pandemik dönemde 14 (\%39) hastada tercih edildi. Otuz altı hastanın dördü COVID- 19 için pozitifti ve bunlardan biri PC grubunda idi. PC grubunda kardiyak arrest nedeniyle bir (\% 7.I) mortalite vardı. Gruplar arasında hastanede kalış süresi istatistiksel olarak anlamlı değildi.

TARTIŞMA: Pandemi döneminde LC önerilmemektedir, bu nedenle PC AC tedavisinde etkili ve güvenli bir alternatif olabilir.

Anahtar sözcükler: Akut kolesistit; COVID-19 pandemisi; perkütan kolesistostomi.

Ulus Travma Acil Cerrahi Derg 2021;27(I):89-94 doi: 10.14744/tjtes.2020.69804 